\title{
Cell-Mediated Delivery of Nanoparticles: Taking Advantage of Circulatory Cells to Target Nanoparticles
}

\author{
Aaron C. Anselmo and Samir Mitragotri ${ }^{*}$ \\ Department of Chemical Engineering Center for Bioengineering University of California, Santa \\ Barbara, CA 93106
}

\section{Abstract}

Cellular hitchhiking leverages the use of circulatory cells to enhance the biological outcome of nanoparticle drug delivery systems, which often suffer from poor circulation time and limited targeting. Cellular hitchhiking utilizes the natural abilities of circulatory cells to: (i) navigate the vasculature while avoiding immune system clearance, (ii) remain relatively inert until needed and (iii) perform specific functions, including nutrient delivery to tissues, clearance of pathogens, and immune system surveillance. A variety of synthetic nanoparticles attempt to mimic these functional attributes of circulatory cells for drug delivery purposes. By combining the advantages of circulatory cells and synthetic nanoparticles, many advanced drug delivery systems have been developed that adopt the concept of cellular hitchhiking. Here, we review the development and specific applications of cellular hitchhiking-based drug delivery systems.

\section{Keywords}

cellular hitchhiking; cell-mediated drug delivery; nanomedicine; nanotechnology; nanoparticles; blood

\section{Introduction}

Cell-based therapies have been used for several centuries as the first documented case of a blood transfusion into humans dating back to 1667 [1]. In the modern era of medicine, numerous advancements have been made that utilize cell's natural abilities for specific therapeutic outcomes, including transfusions of specific blood components [2] (i.e. red blood cell, white blood cell, plasma or platelet transfusions), immunotherapies for the treatment of cancers [3] and recent breakthroughs using mesenchymal stem cells for tissue regeneration [4]. Indeed, circulatory cells offer an attractive candidate to form the basis of therapies capable of performing functions that often limit the applications of synthetic

\footnotetext{
(C) 2014 Elsevier B.V. All rights reserved.

* To whom correspondence should be addressed: Prof. Samir Mitragotri, Department of Chemical Engineering, University of California, Santa Barbara, CA 93106, Ph: 805-893-7532, Fax: 805-893-4731, samir@ engineering.ucsb.edu.

Publisher's Disclaimer: This is a PDF file of an unedited manuscript that has been accepted for publication. As a service to our customers we are providing this early version of the manuscript. The manuscript will undergo copyediting, typesetting, and review of the resulting proof before it is published in its final citable form. Please note that during the production process errors may be discovered which could affect the content, and all legal disclaimers that apply to the journal pertain.
} 
materials [5]. This originates from the fact that cells are nature's own 'delivery vehicles' as they have evolved to optimally perform delivery functions in vivo.

Apart from blood transfusions, many cell-based therapies take advantage of cell's abilities to enhance the therapeutic effect of synthetic materials (i.e. drugs) or biological materials (i.e. antigens). Many formulations focused on leveraging circulatory cell's natural functions combined with either synthetic or biological materials for a therapeutic outcome have been developed and used for various in vivo applications (Table 1). An excellent example of such systems is adjuvant-supplemented adoptive cell therapy [6].

Synthetic materials are significantly limited in their ability to circulate, target and negotiate cellular barriers on their own and are thereby limited in their clinical utility. It is essential to develop technologies to overcome these inherent limitations, and in fact, polymeric nano/ micro-particles are widely researched to improve the biological outcome of therapeutics such as free drugs, antibodies and antigens [7]. Extensive research efforts are focused on cell-inspired drug delivery systems, including entirely synthetic cells $[8,9]$, cell-membrane coated nanoparticles [10,11], and nanoparticles functionalized with marker of "self" peptides to avoid immune system recognition [12]. Other biological or cell-inspired delivery systems have been reviewed elsewhere [5] and are beyond the scope of this article.

Therapeutic nanoparticles would directly benefit from mimicking the functions of circulatory cells. Combining synthetic carriers with circulatory cells thus offers an ideal design paradigm for nanomedicine. This forms the basis for cellular hitchhiking. This review focuses on the design parameters and applications of cellular hitchhiking-based drug delivery systems that have been tested in vivo (Table 2). This review provides a summary of various aspects of cellular-hitchhiking including: (i) cell choice, (ii) cell-particle attachment/ incorporation methods, (iii) preservation of cell integrity and function and (iv) in vivo applications.

\section{Nanoparticle Drug Delivery Systems}

Nanoparticle drug delivery systems represent one of the most widely researched methods for improving circulation time, bioavailability and targeting of numerous therapeutics $[7,13$, 14]. Nanoparticles offer many advantages over their free drug counterparts. Notably, nanoparticles are capable of: (i) encapsulating and protecting drugs from degradation or deactivation prior to reaching target site in vivo, (ii) improving targeting over free drugs via presentation of tissue-specific targeting ligands, (iii) offering controlled drug release by modifying nanoparticle polymer composition, and (iv) production in large, reproducible, batches (Fig. 1A).

In theory, nanoparticles hold the potential to be the ideal drug delivery carrier. Unfortunately, the rapid clearance of nanoparticles from blood and limited targeting to specific tissues has prevented the overwhelming majority of nanoparticles from entering the clinic [15]. The most researched method to circumvent clearance is to coat nanoparticles with polyethylene glycol (PEG), a hydrophilic polymer, onto the surface of nanoparticles to increase circulation time up to 1 week as compared to a few minutes for non-PEG nanoparticles [14]. Recently, however, it has been shown that this technique causes 
generation of PEG-specific IgM antibodies which results in accelerated clearance of PEG particles upon repeated doses [16-19]. In addition, modification of nanoparticles with targeting ligands can potentially compromise the ability of the nanoparticle to perform stealth functions [20]. Hence, nanoparticles must be multifunctional and able to perform these functions simultaneously. Indeed, this is the biggest challenge in nanoparticle design. Table 3 lists: (i) the properties of the ideal drug delivery carrier, (ii) how nanoparticles can potentially perform the functions of an ideal drug delivery carrier, (iii) limitations that prevent nanoparticles from fulfilling this potential and (iv) properties of cells that can address these hurdles via cellular hitchhiking.

\section{Cell Choices for Cellular Hitchhiking}

Circulatory cells have innate properties such as unparalleled circulation throughout the body, natural delivery mechanisms, natural stealth properties and the ability to negotiate and cross near-impermeable biological barriers, which make them attractive candidates for nanoparticle drug delivery vehicles. These features arise from the unique structure, mechanical properties and surface ligands of each specific cell type. Indeed, each circulatory cell is unique and designed to perform distinct functions (Fig. 1B); therefore, familiarity of these distinct cellular functions is essential in developing a successful cellular hitchhiking formulation.

\section{Red Blood Cells}

Red blood cells are the most abundant circulatory cells in the body and have been used as drug carriers for a variety of cell-based therapies [21-23]. In fact, red blood cells interact with and partition over 40 known intravenously administered drugs via mechanisms ranging from dissolution into the red blood cell lipid bilayer membranes, passive diffusion, or even binding to red blood cell components such as hemoglobin, thereby naturally altering the biodistribution and pharmacokinetics of free drugs [24]. Red blood cells are also responsible for the delivery of oxygen to all parts of the body and can circulate for up to 3 months [21]. These unique abilities are directly attributed to red blood cell's structure and mechanical properties. Specifically, red blood cells are biconcave in shape which, in osmotic solutions, grants them high surface area. This permits their reversible deformation while navigating through capillaries often smaller in diameter than the cells themselves, contributing to red blood cells being the most mobile circulatory cell. Red blood cells are also highly flexible, which further facilitates this navigation and reversible deformation through blood vessels. Long circulation times and oxygen delivery are, in part, governed by the surface ligands on red blood cells. CD47, a marker of self, is a surface protein that effectively acts as a cellular passport, granting passage through the immune system and granting red blood cells their stealth properties [12].

For the reasons stated above, red blood cells have extensively been researched for use as drug delivery vehicles (Table 1). To list few other examples, red blood cells have been successfully used in humans for the prolonged (7 days) release of a number of antiinflammatory corticosteroids which were loaded inside red blood cell interior [25]. Building on the eventual blood clearance of red blood cells, antigens have been conjugated to the surface of red blood cells and delivered directly to immune cells for T-cell deletion 
applications [26]. Further, intraperitoneal injected HSV-1 glycoprotein B modified red blood cells have successfully been used for HSV-1 vaccinations, preventing lethal development of HSV-1 [27]. However, only recently have red blood cells been investigated for cellular hitchhiking applications [28-30]. By attaching nanoparticles to the surface of red blood cells it has been possible to transfer some of the unique properties of red blood cells to nanoparticles in vivo, specifically enhancing the circulation time of nanoparticles [28, 29]. This technique can perhaps circumvent many of the issues nanoparticles inherently face in vivo, notably the rapid clearance and poor circulation times of nearly all nanoparticles. Further, by incorporating the controlled release abilities of nanoparticles it may be possible to develop a nanoparticle delivery system that not only circulates for a long period of time, but also releases therapeutics in a controlled manner. This system would have great benefits in prolonged circulation and release of detoxifying enzymes, possibly in the case of alcohol poisoning. It may also be possible to deliver nanoparticles to areas of the body that receive high cardiac output and target delivery of therapeutic nanoparticles to nearby pathologies.

\section{Macrophages and Monocytes}

Monocytes are white blood cells that are the precursors to macrophages [31]. Monocytes are typically stored in the spleen and circulate through the vasculature until terminally differentiating into macrophages. During this process, monocytes travel from the blood through the endothelial barrier and penetrate deep into each organ where they ultimately reside [32]. This process occurs naturally and ensures that macrophages in tissues are constantly replenished. Once reaching there, macrophages can phagocytose and effectively clear foreign materials traveling in blood. Monocytes are also known to reach many areas of the body that nanoparticles struggle to, such as: (i) migrating to diseased sites that give off inflammation signals, such as tumors [33], (ii) crossing the blood brain barrier [31] to reach inflamed brain tissue, as in the case of Parkinson's and Alzheimer's disease and (iii) reach the hypoxic areas of tumors that lack blood flow before differentiating into tumor associated macrophages [34].

These unique abilities of monocytes and macrophages mimic the properties of an ideal drug carrier. Several monocyte/macrophage-inspired drug delivery systems using nanoparticles have been conceived [35]. Direct loading of free drugs in macrophages can result in low drug loading or premature drug release and limited drug delivery to target cells [35]. Therefore, nanoparticles may be an ideal carrier for monocyte/macrophage-mediated drug delivery due to their ability to encapsulate, protect and release controlled amounts of therapeutics. The potential for monocytes to cross barriers, such as the blood-brain barrier, and carry therapeutic nanoparticles from circulation to the regions of the body that are difficult to reach, such as hypoxic areas in tumor, is also appealing. This can potentially circumvent the issues of limited tissue penetration that nanoparticle therapies typically suffer from. Indeed, macrophage-based systems have recently been researched to assess their abilities to deliver nanoparticles to these difficult to reach sites (Table 2).

\section{T-Cells and B-Cells}

Lymphocytes including T-cells, B-cells and natural killer cells are white blood cells that make up the adaptive immune system. T-cells are primarily responsible for cell-mediated 
immunity with different subsets of T-cells responsible for different functions: (i) cytotoxic T-cells are responsible for destroying infected cells [36] (ii) helper T-cells facilitate the maturation of B-cells and activation of cytotoxic T-cells [37] and (iii) memory T-cells, which persist in tissues following infection, retain antigen information so as to generate a rapid immune response to a previously encountered antigen [38]. B-cells, on the other hand, synthesize antibodies and antigens in order to facilitate the creation of memory B-cells [39].

The specific functions of T-cells are widely used to combat various cancers and tumors in the form of immunotherapies [40]. T-cell based immunotherapies targeting cancer rely on the natural functions of T-cells to seek and destroy cancer cells. In these cases T-cells are either: (i) isolated from patient tumors, proliferated in vitro and re-introduced into the patient to increase the number of tumor specific cytotoxic T-cells [41] or (ii) genetically engineered to attack tumor specific antigens [42, 43]. However, upon introduction of adoptive T-cells into the body, tumor's natural immunosuppressive environment prevents both the continued proliferation and cytotoxic activities of these primed T-cells [44]. Indeed, the immunosuppressive nature of tumors represents the biggest obstacle in adoptive T-cell therapies that aim to take advantage of the unparalleled ability of T-cells to target and kill cancer cells. Many different strategies have been employed to circumvent these issues, however, only recently has the inclusion of nanoparticles (cellular hitchhiking) been used to not only improve the cytotoxic abilities of T-cells, but also to enhance their persistence and proliferation at the tumor sites (Table 2).

\section{Other Circulatory Cells}

Other circulatory cells can potentially be used as platforms for cellular hitchhiking. Dendritic cells have been used in cell therapies as therapeutic cancer vaccines [45]. The main role of dendritic cells is to serve as antigen presenting cells that aid in the activation of T-cells [46]. Natural killer cells attack and kill tumor cells; in fact, this process is independent of tumor specific antigens, unlike T-cell mediated cytotoxicity. This may make them an interesting alternative to T-cell immunotherapies, provided their isolation and $e x$ vivo expansion can be improved [47]. Platelets, which are responsible for maintaining and catalyzing hemostasis [48], also find utility in tissue repair. As a primary component in platelet rich plasma therapies, platelets can be used to improve healing of tendons, bones, muscles and other tissues [49]. These cells, in addition to red blood cells, macrophages, monocytes, T-cells and B-cells, perform distinct functions that regulate normal processes in the body. These highlighted cells have been used for therapeutic functions, and recent works are investigating the potential these cells have for either improved delivery of therapeutic nanoparticles or utilizing nanoparticles that improve the natural therapeutic function of the cell itself. The first step, in either case, is to incorporate nanoparticles either inside of or on the surface of circulatory cells.

\section{Attachment of Nanoparticles to Cells}

Circulatory cells, being biological entities, are comprised of biomolecules such as proteins, lipids and polysaccharides which offer a range of functional groups and surface properties that permit the use of numerous techniques to attach nanoparticles to their surface. Both non-covalent and covalent techniques have been used to attach or conjugate nanoparticles to 
the surface of circulatory cells [50]. Each method offers unique advantages and disadvantages that should be considered depending on both the cell and nanoparticle to be used for cellular hitchhiking. Table 4 provides a schematic for the association of nanoparticles with circulatory cells for cellular hitchhiking applications via (i) adsorption, (ii) ligand-receptor attachment, (iii) covalent coupling and (iv) internalization. The advantages, disadvantages and potential ideal cell candidates are summarized further in Table 4 and discussed in more detail, alongside specific examples, below.

\section{Adsorption}

Perhaps the simplest method for nanoparticle attachment is their passive adsorption on the surface of cells. The surface of mammalian cells is negatively charged [51], arising from negatively charged phosphate, carboxylate and sialic acid groups found on biomolecules. These natural properties of cells provide a simple method to attach cationic nanoparticles to their surface via electrostatic interactions, however, positively charged nanoparticles have shown to be potentially toxic to cells $[52,53]$. In addition to electrostatic interactions, it is hypothesized that the passive adsorption of nanoparticles to the surface of red blood cells (Fig. 2A) is mediated via hydrophobic interactions, van Der Waals forces and hydrogen bonding [28-30]. While these interactions have not been directly studied with red blood cells, many studies investigating the nature of protein adsorption to the surface of polystyrene nanoparticles support this hypothesis since red blood cell membranes are rich in proteins $[54,55]$. The advantages of passive adsorption of nanoparticles on circulatory cells are that this method requires the least modification of the cell and the nanoparticle, provided that the nanoparticle is either positively charged or sufficiently hydrophobic. Previous examples of nanoparticle adsorption on red blood cells have shown that detachment is sheardependent and somewhat predictable [29]; however, the attachment strength between particle and cell may be difficult to control and can result in unpredictable behavior and detachment in vivo.

\section{Ligand-Receptor Attachment}

Another method that requires no cell modification is to utilize ligand-receptor interactions that are mediated by naturally present receptors on the surface of the hitchhiked cells. The CD44-hyaluronic acid interaction has been used for a variety of cell types to mediate the attachment of cellular backpacks to the surface of white blood cells, notably T-cells (Fig. 2B inset i) [56], B- cells (Fig. 2B inset ii) [56-58], and macrophages (Fig. 2B) [59]. The advantages of ligand- receptor attachment are that attachment to target cells is: (i) reliable and reproducible, (ii) simple if target cells are purified and (iii) can potentially be translated into in vivo binding in case of specific ligand-receptor pairs. Further, it allows for the design of a platform technology to attach to a multitude of cell types by simply altering the attachment ligand on the particle surface which is ideal for particle technology that can be scaled-up. On the other hand, these ligand-receptor systems can be disadvantageous if the binding affinity between ligand-receptor is not sufficiently strong to maintain attachment until the target site is reached. Furthermore, many receptors are present on numerous cells which can lead to attachment to undesired cells or responsible for certain biological responses and may be triggered upon ligand interaction and activation. 


\section{Covalent Coupling}

Methods involving the modification of both particle and cell have been utilized to provide covalent bonding, which is stronger than either adsorption or ligand-induced binding. Cell surfaces are rich in proteins which provide functional groups in the form of amines and thiols. Indeed, thiol rich T-cells have been used to covalently conjugate liposomes to their surface via thiol-reactive maleimide groups present on the liposomes (Fig. 2C) [60]. Using this strategy, upwards of 100 nanoparticles per cell were conjugated without causing toxicity or affecting innate cellular functions, in this case, in vivo migration to tumor sites [60]. Further, this thiol-mediated covalent bonding showed prolonged surface retention and avoided particle internalization by T-cells, in contrast with studies that targeted nanoparticle attachment to either the CD3 or CD8 receptors on T-cell surfaces. This provides an obvious advantage that it allows the strong coupling of nanoparticles to the surface of cells while avoiding any potential receptor activated cellular functions from triggering. In addition, stronger binding provided by covalent bonding should limit the detachment and uptake of particles in non-target tissues such as the liver and spleen, which could potentially make covalent coupling more useful in situations where the hitchhiked cell possesses its own targeting abilities as is the case for T-Cells and monocytes/macrophages.

\section{Internalization of Nanoparticles}

A separate technique utilizes certain cell's natural ability to phagocytose foreign materials, coined the "Trojan Horse" method. For cellular hitchhiking, this means utilizing cells capable of phagocytosis to internalize nanoparticles. This is typically performed by incubating nanoparticles with either macrophages or monocytes, ex vivo, and allowing the cells sufficient time to internalize the nanoparticles. Using this strategy, a variety of carriers ranging from gold nanoparticles (Fig. 2D) [61] to nano-formulated catalase complexes, called nanozymes [62, 63], (Fig. 2E) have been incorporated into macrophages. This method leaves the cell membrane unaltered and can potentially protect the nanoparticles from interacting with non-target tissue in vivo. This method is unfortunately limited to cell types that can perform phagocytosis such as macrophages and monocytes. Furthermore, following phagocytosis, biodegradable nanoparticles can be degraded within the cell which can result in premature drug release in case of this "Trojan Horse" method.

\section{Limiting Cellular Damage and Maintaining Cellular Functions Following Nanoparticle Conjugation}

The prospect of utilizing circulatory cells for enhanced drug delivery is dependent on the cell's ability to maintain their innate functions. Therefore, it is essential to verify that particle attachment does not impair or disrupt any of the innate functions of the hitchhiked cell. Additionally, attachment or internalization of nanoparticles cannot be toxic or damaging to the cell. To this end, determining the extent of cellular damage and impairment of cellular functions following nanoparticle attachment has been widely investigated. Indeed, it is not possible to test if every function of each cell is impaired following particle attachment; however, determining if the unique cellular functions that are to be transferred to the particle are still viable is essential. 
As discussed earlier, red blood cells are an ideal cell for cellular hitchhiking given their long circulation lifetimes and abilities to navigate the vasculature due to their highly flexible cell membrane. To take advantage of these attractive abilities, particle attachment to red blood cells must not interfere with their circulation patterns. Recently, our lab has shown that $200 \mathrm{~nm}$ polystyrene nanoparticles adsorbed onto the surface of red blood cells do not cause changes in circulation times at low loading ( 3-4 nanoparticles per red blood cell), however, at high loading ( 24 nanoparticles per red blood cell) it appears that red blood cells are cleared from circulation more rapidly than their naïve counterparts, perhaps due to immune system recognition of red blood cells that had more nanoparticles attached [30]. Further, organ distribution of red blood cells, at 1 hour and 24 hours, was not altered in the spleen, the organ known for clearing and sequestering damaged red blood cells. In these same studies, it was shown that nanoparticle attachment to red blood cells caused no significant hemolysis. Upon shear-induced detachment of nanoparticles following membrane fixation, red blood cells exhibited nanoparticle-sized dents on their surface, suggesting that adhesion of nanoparticles is due to the spreading of the red blood cell membranes (Fig. 3Ai).

However, when detachment of nanoparticles was performed prior to membrane fixation, no dents were found suggesting that the red blood cells membrane reversibly returns to their original morphology (Fig. 3Aii).

Macrophages are known to phagocytose foreign objects as well as to migrate through endothelial cells prior to residing in either inflamed tissue or hypoxic areas of tumors. Previous studies have shown that macrophages functionalized with cellular backpacks on their surface are still able to internalize polystyrene spheres similar to their naïve counterparts (Fig. 3B) [59]. In the same study, it was shown that backpack attachment to macrophages caused no significant cytotoxicity and that motility of macrophages was not impaired. High motility is an important feature for macrophages as they can potentially carry a variety of chemo therapeutics during their migration through and into tumor tissue. Indeed, macrophages that have been loaded (internalized) with catalase-based micelles were as successful as naive macrophages in adhering to and subsequently crossing a confluent layer of bovine brain microvessel endothelial cells, which typically line the difficult to cross blood brain barrier [63, 64]. Along the same lines, gold nanoshells were loaded into macrophages via phagocytosis and were able to migrate to and cross into tumor spheroids, effectively localizing in the hypoxic areas of the tumor spheroid (Fig. 3C) [61].

Lymphocytes are responsible for immune surveillance and are known to migrate to tumor sites to eliminate cancer cells. Similar to macrophages, T-cells have been modified with cellular backpacks via the CD44 receptor and were investigated for their ability to migrate on ICAM-1 coated surfaces, a cellular adhesion ligand present on endothelial cells that mediates the adhesion and subsequent transmigration of leukocytes. One closely monitored T-cell was able to migrate (average 0.5 microns per minute) over an ICAM- 1 coated surface for over 6 hours until the cellular backpack detached, at which point the T-cell continued to migrate over the ICAM-1 surface (Fig. 3D) [56]. In a separate study, T-cells that had their surface conjugated with up to 100 adjuvant loaded liposomes that are designed to increase $\mathrm{T}$-cell efficacy in killing target cells and promote differentiation of transferred T-cells, maintained their cytotoxic abilities against target cells in vitro. T-cells were also able to 
transmigrate across an endothelial layer keeping up to $83 \%$ of their nanoparticle load during transmigration [60]. Transmigration of T-cells following nanoparticle conjugation is essential if the T-cells are to reach the target cells, in this case reaching cancer cells that reside past the endothelium, deep into the tumor. Furthermore, preservation of liposome load, and subsequently adjuvant potency, is required to maintain T-cell function when successfully transmigrated and localized near target cells in tumors. In a follow up study, nanoparticles were conjugated to the surface of T-cells in a similar way and, upon T-cell interaction with target cancer cells, redistributed at the point of T-cell-cancer cell contact and did not interfere with either target cell killing or cytokine release from the T-cell (Fig. 3E) [65]. In this case, the liposomes were loaded with inhibitors that prevent the downregulation of T-cell receptor activation, thereby improving T-cells ability to kill target cancer cells. In the original study, plain liposomes covalently attached to T-cells, which had specific affinity towards OVA, were able to retain their innate OVA-tumor homing ability and selectively home to EG7-OVA expressing tumors that were established opposite EL4 tumors (Fig. 3F). In this case, a 176-fold increase in nanoparticle accumulation for liposomes conjugated to T-cells over bare liposomes [60].

\section{Cellular Hitchhiking Improves Nanoparticle Function In Vivo}

Cellular hitchhiking must facilitate the transfer of certain cellular functions to nanoparticles in order to improve upon current drug delivery nanoparticle formulations. Specifically, nanoparticles must perform better, when hitchhiked onto cells, in vivo in terms of circulation time, targeting and migration from the vasculature into diseased tissue, when necessary. Circulatory cells are designed to navigate the vasculature and avoid clearance by the body, so it is expected that hitchhiked nanoparticles should circulate for longer times than their non-hitchhiked counterparts. Proteins, such as CD47, found on the surface of red blood cells and other cells act as stealth molecules that allow the passage of circulatory cells through barriers and obstacles that foreign entities, including nanoparticles and bacteria, are not permitted [12].

By attaching nanoparticles to the surface of red blood cells, certain stealth abilities can be transferred from cell to nanoparticle. Nanoparticles adsorbed onto red blood cells show prolonged circulation time in rats. Specifically, hitchhiked nanoparticles remained in blood circulation for over 10 hours as compared to 5 minutes for bare nanoparticles [29]. In a follow up study in mice, avoidance of the two main clearance organs, the liver and spleen, was achieved by adsorbing $200 \mathrm{~nm}$ polystyrene nanoparticles to the surface of red blood cells. In this same study, $\sim 7$-fold increase in lung accumulation was seen for hitchhiked nanoparticles compared to free nanoparticles [30]. Interestingly, this lung targeting was not ligand-based as most targeted nanoparticle formulations are. Instead, it was a mechanicallydriven targeting mechanism that relied on the red blood cells close proximity to the endothelium (25\% of which is located in lungs) during blood flow to facilitate the sheardependent detachment of nanoparticles from red blood cell surface in the lungs. This lung accumulation was further increased to $\sim 10$ fold compared to free nanoparticles by conjugating the lung targeting ligand, ICAM-1 antibody, exclusively to the surface of the hitchhiked nanoparticles. 
Unlike red blood cells, monocytes and macrophages are able to target and cross the endothelial barriers that often separate circulating blood and diseased tissues. Macrophages derived from the bone marrow have shown to be capable of transporting therapeutic nanoparticles from circulation to diseased tissues. Due to monocyte's ability to cross endothelial barriers, these systems are best suited for nanoparticles that are internalized by macrophages so as to prevent detachment during the transmigration process. Bone marrow derived macrophages have been used to treat HIV infection in brain tissue. First, macrophage infiltration into target brain tissue was confirmed by histology of mice infected with HIV (Fig. 4A). Indinavir was then encapsulated within the nanoparticles and delivery via macrophages to brain tissue allowed for drug release over a 2 week period in the brain and subsequent suppression of HIV infected tissue (Fig. 4B) [66]. Bone marrow derived macrophages have also been used to deliver internalized antioxidant enzyme catalase nanoparticles, termed nanozymes, across the blood brain barrier. In the first of such studies, a Parkinson's disease model using MPTP-intoxicated mice showed that it was possible to target macrophages containing nanozymes to neuroinflammation [62]. In a follow up study, the delivery of nanozymes via macrophages was tracked in real time and showed increased nanozyme, and likely catalase, persistence in the brain of MPTP intoxicated mice as compared to nanozymes alone (Fig. 4C) [63].

Nanozymes delivered via macrophages were able to prevent neuroinflammation, reduce astrocytosis, reduce oxidative stress, increase neuron survival and induce a neuroprotective effect that prevents inflammation in the brains of MPTP-intoxicated mice. Other studies have focused on cancer targeting using liposomal doxorubicin encapsulated by peritoneal mouse macrophages to cause $\sim 50 \%$ decrease in growth (volume) of tumors compared to PBS control [68]. In a brain metastases model, human blood derived monocytes/ macrophages were used to chauffer 40nm nanoparticles through the blood brain barrier in mice and localize at the sites of tumor metastases (Fig. 4D) [67].

T-cells, which have been researched extensively for adoptive cell therapies for cancer treatment, have had many of their natural anticancer functions improved via cellular hitchhiking. Adoptive cell therapies must be able to promote persistence of donor cells and efficiently kill target cells; however, the immunosuppressive tumor environment actively prevents both of these from ensuing. To bypass these issues, adoptive cell therapies have relied on supplemental adjuvant drugs to tumor sites. Unfortunately, these drugs suffer from the same limitations that all untargeted molecules suffer from. Recently, adjuvant-loaded liposomes that promote donor cell persistence and target cell interaction have been covalently coupled to T-cells, thereby ensuring adjuvant delivery to donor T-cells. Two separate cytokines that synergistically promote T-cell proliferation and effector function were encapsulated into T-cell bound liposomes. To determine whether adjuvant loaded and T-cell conjugated liposomes could improve therapeutic function of T-cells, lung and bone metastases were developed in mice and standard adoptive cell therapies with adjuvant supplementation were directly compared with adjuvant-liposome modified T-cells. In the case of liposome-adjuvant modified T-cells, a marked increase in donor T-cells was reported for the entire duration and complete eradication of metastases was reported (Fig. 4E) [60]. In a follow up study, T-cells functionalized with nanoparticles which contained inhibitors that 
prevent downregulation of T-cell receptor activation, allowed for a 14 day survival advantage, over T-cell only groups, in mice with advanced prostate cancer [65].

\section{Future Challenges}

While cellular hitchhiking-based drug delivery systems have shown their promise, several future challenges remain. The primary challenge is that the field is in early stages and most studies to date have been performed in small animals. Translation of the results from small animals to larger animals and eventually to humans needs to be demonstrated. This challenge, as such, is not different than what other drug delivery systems face; however, the challenges associated with this translation should be identified soon so as to develop necessary strategies. Another potential challenge is that cell therapies can be very expensive. The costs stem from using a patient's own cells that are individually prepared for each patient. This challenge could be potentially addressed by developing strategies to attach nanoparticles to cells in vivo, which will reduce the logistics of the cell-based therapy to that of any other nanoparticle-based method. Circulatory cells also have multiple functions and it may prove difficult to utilize specifically chosen functions. Often, the effects of removing cells, modifying them and subsequently reintroducing them can cause unpredictable side effects. The potential for modified cells to go renegade and target undesirable tissues needs further investigation. Determining mechanisms and exact locations of particle detachment from cells in vivo, especially in cases of covalent or strong ligand-receptor attachment, needs further assessment. Until this point, most studies showing in vivo therapeutic application have not investigated particle detachment as they have focused on the use of biodegradable particles which do not require detachment for therapeutic effect. Regardless of these challenges, it is clear that cellular hitchhiking provides a specific means of addressing the current limitations of drug delivery nanoparticles. Future studies should focus on addressing these hurdles and explore further applications of cellular hitchhiking.

\section{Acknowledgments}

A.C.A. was supported by the National Science Foundation Graduate Research Fellowship under Grant No. DGE-1144085.

\section{References}

1. Myhre BA. The first recorded blood transfusions: 1656 to 1668 . Transfusion. 1990; 30:358-62. [PubMed: 2190368]

2. Klein, HG.; Anstee, DJ. Mollison's blood transfusion in clinical medicine. Wiley. com; 2008.

3. Rosenberg SA, Yang JC, Restifo NP. Cancer immunotherapy: moving beyond current vaccines. Nat Med. 2004; 10:909-15. [PubMed: 15340416]

4. Caplan AI. Adult mesenchymal stem cells for tissue engineering versus regenerative medicine. $\mathrm{J}$ Cell Physiol. 2007; 213:341-7. [PubMed: 17620285]

5. Yoo JW, Irvine DJ, Discher DE, Mitragotri S. Bio-inspired, bioengineered and biomimetic drug delivery carriers. Nat Rev Drug Discov. 2011; 10:521-35. [PubMed: 21720407]

6. Mellman I, Coukos G, Dranoff G. Cancer immunotherapy comes of age. Nature. 2011; 480:480-9. [PubMed: 22193102]

7. Petros RA, DeSimone JM. Strategies in the design of nanoparticles for therapeutic applications. Nat Rev Drug Discov. 2010; 9:615-27. [PubMed: 20616808] 
8. Doshi N, Orje JN, Molins B, Smith JW, Mitragotri S, Ruggeri ZM. Platelet mimetic particles for targeting thrombi in flowing blood. Adv Mater. 2012; 24:3864-9. [PubMed: 22641451]

9. Doshi N, Zahr AS, Bhaskar S, Lahann J, Mitragotri S. Red blood cell-mimicking synthetic biomaterial particles. Proc Natl Acad Sci U S A. 2009; 106:21495-9. [PubMed: 20018694]

10. Hu C-MJ, Zhang L, Aryal S, Cheung C, Fang RH, Zhang L. Erythrocyte membrane-camouflaged polymeric nanoparticles as a biomimetic delivery platform. Proceedings of the National Academy of Sciences. 2011; 108:10980-5.

11. Parodi A, Quattrocchi N, van de Ven AL, Chiappini C, Evangelopoulos M, Martinez JO, et al. Synthetic nanoparticles functionalized with biomimetic leukocyte membranes possess cell-like functions. Nat Nanotechnol. 2013; 8:61-8. [PubMed: 23241654]

12. Rodriguez PL, Harada T, Christian DA, Pantano DA, Tsai RK, Discher DE. Minimal "Self" peptides that inhibit phagocytic clearance and enhance delivery of nanoparticles. Science. 2013; 339:971-5. [PubMed: 23430657]

13. Peer D, Karp JM, Hong S, Farokhzad OC, Margalit R, Langer R. Nanocarriers as an emerging platform for cancer therapy. Nat Nanotechnol. 2007; 2:751-60. [PubMed: 18654426]

14. Moghimi SM, Hunter AC, Murray JC. Long-circulating and target-specific nanoparticles: theory to practice. Pharmacological reviews. 2001; 53:283-318. [PubMed: 11356986]

15. Owens DE 3rd, Peppas NA. Opsonization, biodistribution, and pharmacokinetics of polymeric nanoparticles. Int J Pharm. 2006; 307:93-102. [PubMed: 16303268]

16. Dams ET, Laverman P, Oyen WJ, Storm G, Scherphof GL, van Der Meer JW, et al. Accelerated blood clearance and altered biodistribution of repeated injections of sterically stabilized liposomes. J Pharmacol Exp Ther. 2000; 292:1071-9. [PubMed: 10688625]

17. Laverman P, Carstens MG, Boerman OC, Dams ET, Oyen WJ, van Rooijen N, et al. Factors affecting the accelerated blood clearance of polyethylene glycol-liposomes upon repeated injection. J Pharmacol Exp Ther. 2001; 298:607-12. [PubMed: 11454922]

18. Ishida T, Maeda R, Ichihara M, Mukai Y, Motoki Y, Manabe Y, et al. The accelerated clearance on repeated injection of pegylated liposomes in rats: laboratory and histopathological study. Cellular \& molecular biology letters. 2002; 7:286. [PubMed: 12097957]

19. Abu Lila AS, Kiwada H, Ishida T. The accelerated blood clearance (ABC) phenomenon: Clinical challenge and approaches to manage. J Control Release. 2013; 172:38-47. [PubMed: 23933235]

20. Cheng Z, Al Zaki A, Hui JZ, Muzykantov VR, Tsourkas A. Multifunctional nanoparticles: cost versus benefit of adding targeting and imaging capabilities. Science. 2012; 338:903-10. [PubMed: 23161990]

21. Muzykantov VR. Drug delivery by red blood cells: vascular carriers designed by mother nature. Expert opinion on drug delivery. 2010; 7:403-27. [PubMed: 20192900]

22. Pierige F, Serafini S, Rossi L, Magnani M. Cell-based drug delivery. Adv Drug Deliv Rev. 2008; 60:286-95. [PubMed: 17997501]

23. Hamidi M, Tajerzadeh H. Carrier erythrocytes: an overview. Drug Deliv. 2003; 10:9-20. [PubMed: 12554359]

24. Hinderling PH. Red blood cells: a neglected compartment in pharmacokinetics and pharmacodynamics. Pharmacological reviews. 1997; 49:279-95. [PubMed: 9311024]

25. Rossi L, Serafini S, Cenerini L, Picardi F, Bigi L, Panzani I, et al. Erythrocyte-mediated delivery of dexamethasone in patients with chronic obstructive pulmonary disease. Biotechnol Appl Biochem. 2001; 33:85-9. [PubMed: 11277860]

26. Kontos S, Kourtis IC, Dane KY, Hubbell JA. Engineering antigens for in situ erythrocyte binding induces T-cell deletion. Proc Natl Acad Sci U S A. 2013; 110:E60-8. [PubMed: 23248266]

27. Chiarantini L, Argnani R, Zucchini S, Stevanato L, Zabardi P, Grossi MP, et al. Red blood cells as delivery system for recombinant HSV-1 glycoprotein B: immunogenicity and protection in mice. Vaccine. 1997; 15:276-80. [PubMed: 9139486]

28. Chambers E, Mitragotri S. Prolonged circulation of large polymeric nanoparticles by non-covalent adsorption on erythrocytes. J Control Release. 2004; 100:111-9. [PubMed: 15491815]

29. Chambers E, Mitragotri S. Long circulating nanoparticles via adhesion on red blood cells: mechanism and extended circulation. Experimental biology and medicine. 2007; 232:958-66. [PubMed: 17609513] 
30. Anselmo AC, Gupta V, Zern BJ, Pan D, Zakrewsky M, Muzykantov V, et al. Delivering Nanoparticles to Lungs while Avoiding Liver and Spleen through Adsorption on Red Blood Cells. ACS Nano. 2013; 7:11129-37. [PubMed: 24182189]

31. Gordon S, Taylor PR. Monocyte and macrophage heterogeneity. Nat Rev Immunol. 2005; 5:95364. [PubMed: 16322748]

32. Imhof BA, Aurrand-Lions M. Adhesion mechanisms regulating the migration of monocytes. Nat Rev Immunol. 2004; 4:432-44. [PubMed: 15173832]

33. Shi C, Pamer EG. Monocyte recruitment during infection and inflammation. Nat Rev Immunol. 2011; 11:762-74. [PubMed: 21984070]

34. Murdoch C, Giannoudis A, Lewis CE. Mechanisms regulating the recruitment of macrophages into hypoxic areas of tumors and other ischemic tissues. Blood. 2004; 104:2224-34. [PubMed: 15231578]

35. Batrakova EV, Gendelman HE, Kabanov AV. Cell-mediated drug delivery. Expert opinion on drug delivery. 2011; 8:415-33. [PubMed: 21348773]

36. Barry M, Bleackley RC. Cytotoxic T lymphocytes: all roads lead to death. Nat Rev Immunol. 2002; 2:401-9. [PubMed: 12093006]

37. Mosmann TR, Coffman RL. TH1 and TH2 cells: different patterns of lymphokine secretion lead to different functional properties. Annu Rev Immunol. 1989; 7:145-73. [PubMed: 2523712]

38. Sallusto F, Geginat J, Lanzavecchia A. Central memory and effector memory T cell subsets: function, generation, and maintenance. Annu Rev Immunol. 2004; 22:745-63. [PubMed: 15032595]

39. LeBien TW, Tedder TF. B lymphocytes: how they develop and function. Blood. 2008; 112:157080. [PubMed: 18725575]

40. Restifo NP, Dudley ME, Rosenberg SA. Adoptive immunotherapy for cancer: harnessing the T cell response. Nat Rev Immunol. 2012; 12:269-81. [PubMed: 22437939]

41. Dudley ME, Rosenberg SA. Adoptive-cell-transfer therapy for the treatment of patients with cancer. Nat Rev Cancer. 2003; 3:666-75. [PubMed: 12951585]

42. Kerkar SP, Sanchez-Perez L, Yang S, Borman ZA, Muranski P, Ji Y, et al. Genetic engineering of murine CD8+ and CD4+ T cells for preclinical adoptive immunotherapy studies. J Immunother. 2011; 34:343-52. [PubMed: 21499127]

43. Morgan RA, Dudley ME, Wunderlich JR, Hughes MS, Yang JC, Sherry RM, et al. Cancer regression in patients after transfer of genetically engineered lymphocytes. Science. 2006; 314:126-9. [PubMed: 16946036]

44. Viguier M, Lemaitre F, Verola O, Cho MS, Gorochov G, Dubertret L, et al. Foxp3 expressing CD4+CD25(high) regulatory $\mathrm{T}$ cells are overrepresented in human metastatic melanoma lymph nodes and inhibit the function of infiltrating T cells. J Immunol. 2004; 173:1444-53. [PubMed: 15240741]

45. Tacken PJ, de Vries IJ, Torensma R, Figdor CG. Dendritic-cell immunotherapy: from ex vivo loading to in vivo targeting. Nat Rev Immunol. 2007; 7:790-802. [PubMed: 17853902]

46. Timmerman JM, Levy R. Dendritic cell vaccines for cancer immunotherapy. Annu Rev Med. 1999; 50:507-29. [PubMed: 10073291]

47. Childs RW, Berg M. Bringing natural killer cells to the clinic: ex vivo manipulation. Hematology Am Soc Hematol Educ Program. 2013; 2013:234-46. [PubMed: 24319186]

48. Ruggeri ZM. Mechanisms initiating platelet thrombus formation. Thromb Haemost. 1997; 78:6116. [PubMed: 9198225]

49. Foster TE, Puskas BL, Mandelbaum BR, Gerhardt MB, Rodeo SA. Platelet-rich plasma: from basic science to clinical applications. Am J Sports Med. 2009; 37:2259-72. [PubMed: 19875361]

50. Stephan MT, Irvine DJ. Enhancing Cell therapies from the Outside In: Cell Surface Engineering Using Synthetic Nanomaterials. Nano Today. 2011; 6:309-25. [PubMed: 21826117]

51. Weiss L, Zeigel R. Cell surface negativity and the binding of positively charged particles. J Cell Physiol. 1971; 77:179-86. [PubMed: 4102021] 
52. Xia T, Kovochich M, Brant J, Hotze M, Sempf J, Oberley T, et al. Comparison of the abilities of ambient and manufactured nanoparticles to induce cellular toxicity according to an oxidative stress paradigm. Nano Lett. 2006; 6:1794-807. [PubMed: 16895376]

53. Xia T, Kovochich M, Liong M, Zink JI, Nel AE. Cationic polystyrene nanosphere toxicity depends on cell-specific endocytic and mitochondrial injury pathways. ACS Nano. 2008; 2:85-96. [PubMed: 19206551]

54. Yoon J-Y, Park H-Y, Kim J-H, Kim W-S. Adsorption of BSA on highly carboxylated microspheres-quantitative effects of surface functional groups and interaction forces. J Colloid Interface Sci. 1996; 177:613-20.

55. Yoon J-Y, Kim J-H, Kim W-S. Interpretation of protein adsorption phenomena onto functional microspheres. Colloids and Surfaces B: Biointerfaces. 1998; 12:15-22.

56. Swiston AJ, Cheng C, Um SH, Irvine DJ, Cohen RE, Rubner MF. Surface functionalization of living cells with multilayer patches. Nano Lett. 2008; 8:4446-53. [PubMed: 19367972]

57. Swiston AJ, Gilbert JB, Irvine DJ, Cohen RE, Rubner MF. Freely suspended cellular "backpacks" lead to cell aggregate self-assembly. Biomacromolecules. 2010; 11:1826-32. [PubMed: 20527876]

58. Vasconcellos FC, Swiston AJ, Beppu MM, Cohen RE, Rubner MF. Bioactive polyelectrolyte multilayers: hyaluronic acid mediated B lymphocyte adhesion. Biomacromolecules. 2010; 11:2407-14. [PubMed: 20795701]

59. Doshi N, Swiston AJ, Gilbert JB, Alcaraz ML, Cohen RE, Rubner MF, et al. Cell-based drug delivery devices using phagocytosis-resistant backpacks. Adv Mater. 2011; 23:H105-9. [PubMed: 21365691]

60. Stephan MT, Moon JJ, Um SH, Bershteyn A, Irvine DJ. Therapeutic cell engineering with surfaceconjugated synthetic nanoparticles. Nat Med. 2010; 16:1035-41. [PubMed: 20711198]

61. Choi MR, Stanton-Maxey KJ, Stanley JK, Levin CS, Bardhan R, Akin D, et al. A cellular Trojan Horse for delivery of therapeutic nanoparticles into tumors. Nano Lett. 2007; 7:3759-65. [PubMed: 17979310]

62. Batrakova EV, Li S, Reynolds AD, Mosley RL, Bronich TK, Kabanov AV, et al. A macrophagenanozyme delivery system for Parkinson's disease. Bioconjug Chem. 2007; 18:1498-506. [PubMed: 17760417]

63. Brynskikh AM, Zhao Y, Mosley RL, Li S, Boska MD, Klyachko NL, et al. Macrophage delivery of therapeutic nanozymes in a murine model of Parkinson's disease. Nanomedicine. 2010; 5:37996. [PubMed: 20394532]

64. Zhao Y, Haney MJ, Mahajan V, Reiner BC, Dunaevsky A, Mosley RL, et al. Active Targeted Macrophage-mediated Delivery of Catalase to Affected Brain Regions in Models of Parkinson's Disease. Journal of nanomedicine \& nanotechnology. 2011:S4.

65. Stephan MT, Stephan SB, Bak P, Chen J, Irvine DJ. Synapse-directed delivery of immunomodulators using T-cell-conjugated nanoparticles. Biomaterials. 2012; 33:5776-87. [PubMed: 22594972]

66. Dou H, Grotepas CB, McMillan JM, Destache CJ, Chaubal M, Werling J, et al. Macrophage delivery of nanoformulated antiretroviral drug to the brain in a murine model of neuroAIDS. J Immunol. 2009; 183:661-9. [PubMed: 19535632]

67. Choi MR, Bardhan R, Stanton-Maxey KJ, Badve S, Nakshatri H, Stantz KM, et al. Delivery of nanoparticles to brain metastases of breast cancer using a cellular Trojan horse. Cancer nanotechnology. 2012; 3:47-54. [PubMed: 23205151]

68. Choi J, Kim HY, Ju EJ, Jung J, Park J, Chung HK, et al. Use of macrophages to deliver therapeutic and imaging contrast agents to tumors. Biomaterials. 2012; 33:4195-203. [PubMed: 22398206]

69. Murciano JC, Medinilla S, Eslin D, Atochina E, Cines DB, Muzykantov VR. Prophylactic fibrinolysis through selective dissolution of nascent clots by tPA-carrying erythrocytes. Nat Biotechnol. 2003; 21:891-6. [PubMed: 12845330]

70. Magnani M, Fazi A, Mangani F, Rossi L, Mancini U. Methanol detoxification by enzyme-loaded erythrocytes. Biotechnol Appl Biochem. 1993; 18(Pt 3):217-26. [PubMed: 8297502]

71. Fraternale A, Casabianca A, Orlandi C, Cerasi A, Chiarantini L, Brandi G, et al. Macrophage protection by addition of glutathione (GSH)-loaded erythrocytes to AZT and DDI in a murine AIDS model. Antiviral Res. 2002; 56:263-72. [PubMed: 12406509] 
72. Rossi L, Serafini S, Antonelli A, Pierige F, Carnevali A, Battistelli V, et al. Macrophage depletion induced by clodronate-loaded erythrocytes. J Drug Target. 2005; 13:99-111. [PubMed: 15823961]

73. Moyes RB, Kirch H, DeLoach JR. Enhanced biological activity of human recombinant interleukin 2 coupled to mouse red blood cells as evaluated using the mouse Meth A sarcoma model. Biotechnol Appl Biochem. 1996; 23(Pt 1):29-36. [PubMed: 8867894]

74. Hsu FJ, Benike C, Fagnoni F, Liles TM, Czerwinski D, Taidi B, et al. Vaccination of patients with B-cell lymphoma using autologous antigen-pulsed dendritic cells. Nat Med. 1996; 2:52-8. [PubMed: 8564842]

75. Wierecky J, Muller MR, Wirths S, Halder-Oehler E, Dorfel D, Schmidt SM, et al. Immunologic and clinical responses after vaccinations with peptide-pulsed dendritic cells in metastatic renal cancer patients. Cancer Res. 2006; 66:5910-8. [PubMed: 16740731]

76. Mayordomo JI, Zorina T, Storkus WJ, Zitvogel L, Celluzzi C, Falo LD, et al. Bone marrowderived dendritic cells pulsed with synthetic tumour peptides elicit protective and therapeutic antitumour immunity. Nat Med. 1995; 1:1297-302. [PubMed: 7489412]

77. Cole C, Qiao J, Kottke T, Diaz RM, Ahmed A, Sanchez-Perez L, et al. Tumor-targeted, systemic delivery of therapeutic viral vectors using hitchhiking on antigen-specific T cells. Nat Med. 2005; 11:1073-81. [PubMed: 16170322]

78. Rosenberg SA, Restifo NP, Yang JC, Morgan RA, Dudley ME. Adoptive cell transfer: a clinical path to effective cancer immunotherapy. Nat Rev Cancer. 2008; 8:299-308. [PubMed: 18354418]

79. June CH. Adoptive T cell therapy for cancer in the clinic. J Clin Invest. 2007; 117:1466-76. [PubMed: 17549249]

80. Cheng M, Chen Y, Xiao W, Sun R, Tian Z. NK cell-based immunotherapy for malignant diseases. Cell Mol Immunol. 2013; 10:230-52. [PubMed: 23604045]

81. Murray MM, Spindler KP, Abreu E, Muller JA, Nedder A, Kelly M, et al. Collagen-platelet rich plasma hydrogel enhances primary repair of the porcine anterior cruciate ligament. J Orthop Res. 2007; 25:81-91. [PubMed: 17031861] 
(A)

(i)

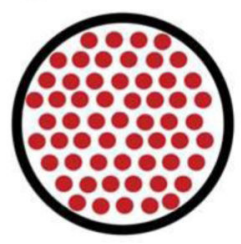

Encapsulate and Protect Drug (ii)

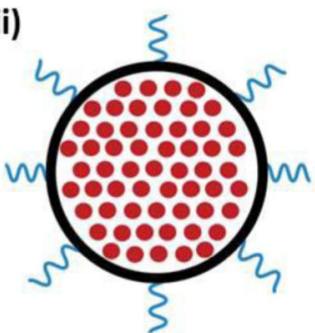

Improve

Targeting (iii)

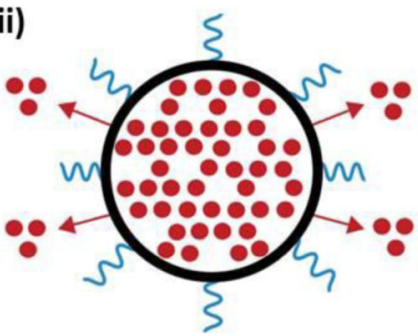

Control Drug

Release (iv)

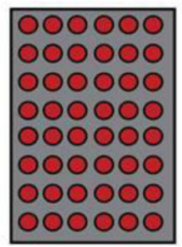

Mass Production

(B)

Platelets:

Mediate Hemostasis and Prevent Blood Loss

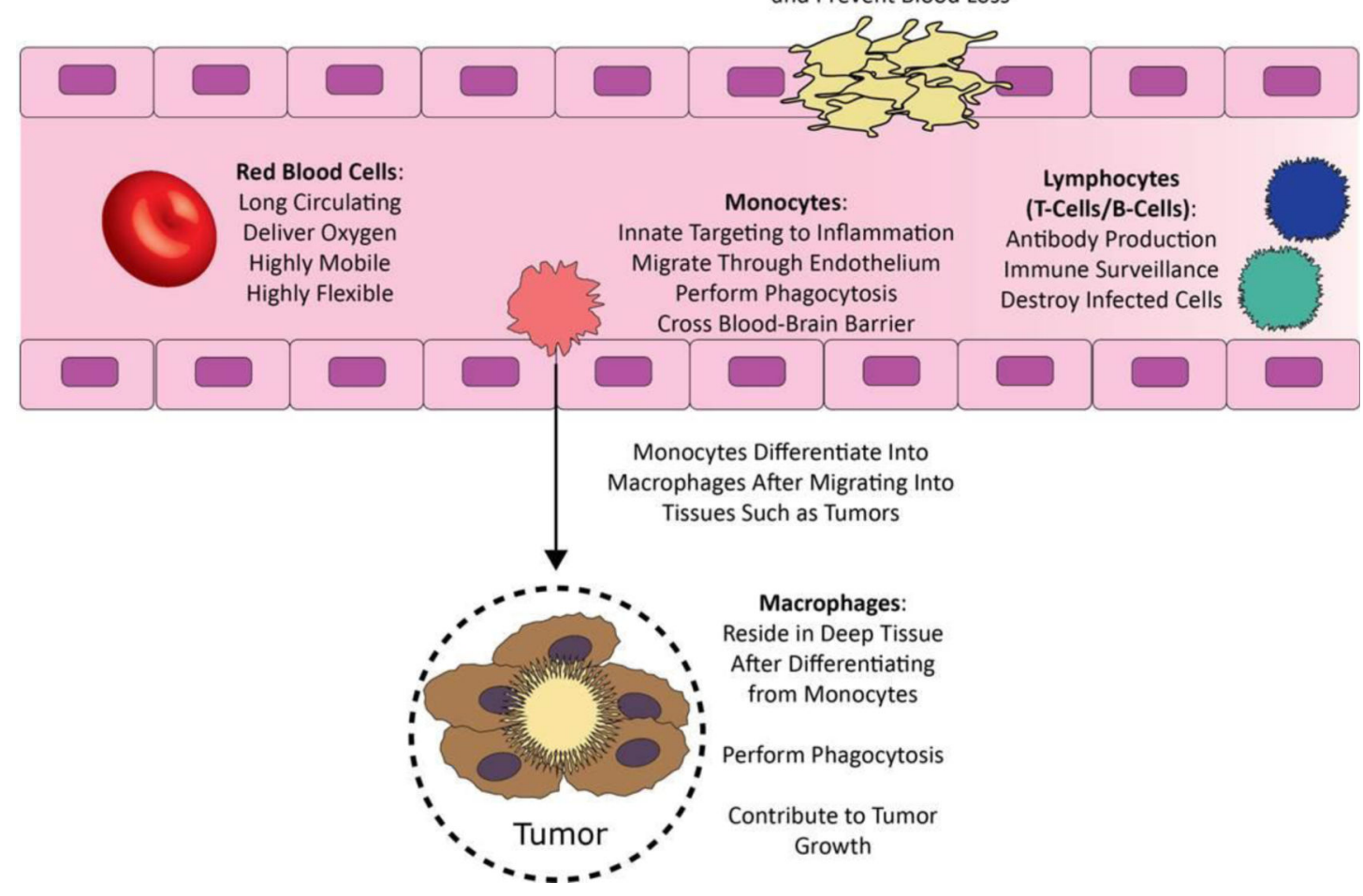

Figure 1.

Advantages of nanoparticles and circulatory cells in drug delivery. (A) Nanoparticle drug delivery systems provide a platform for the synthesis of application specific nanoparticles. Nanoparticles have advantages over their free drug counterparts, such as: (i) the encapsulation and subsequent prevention of rapid degradation of drugs in vivo, (ii) improved targeting via tissue specific ligand conjugation, (iii) controlled rate of drug release via polymer choice and (iv) the potential to mass produce batches of particles. (B) Circulatory cells, including red blood cells, monocytes, platelets, and lymphocytes have natural drug delivery abilities such as: (i) long circulation times, (ii) small molecule delivery systems, 
(iii) high mobility and flexibility, (iv) antibody production, (v) immune surveillance and (vi) inherent targeting abilities. 

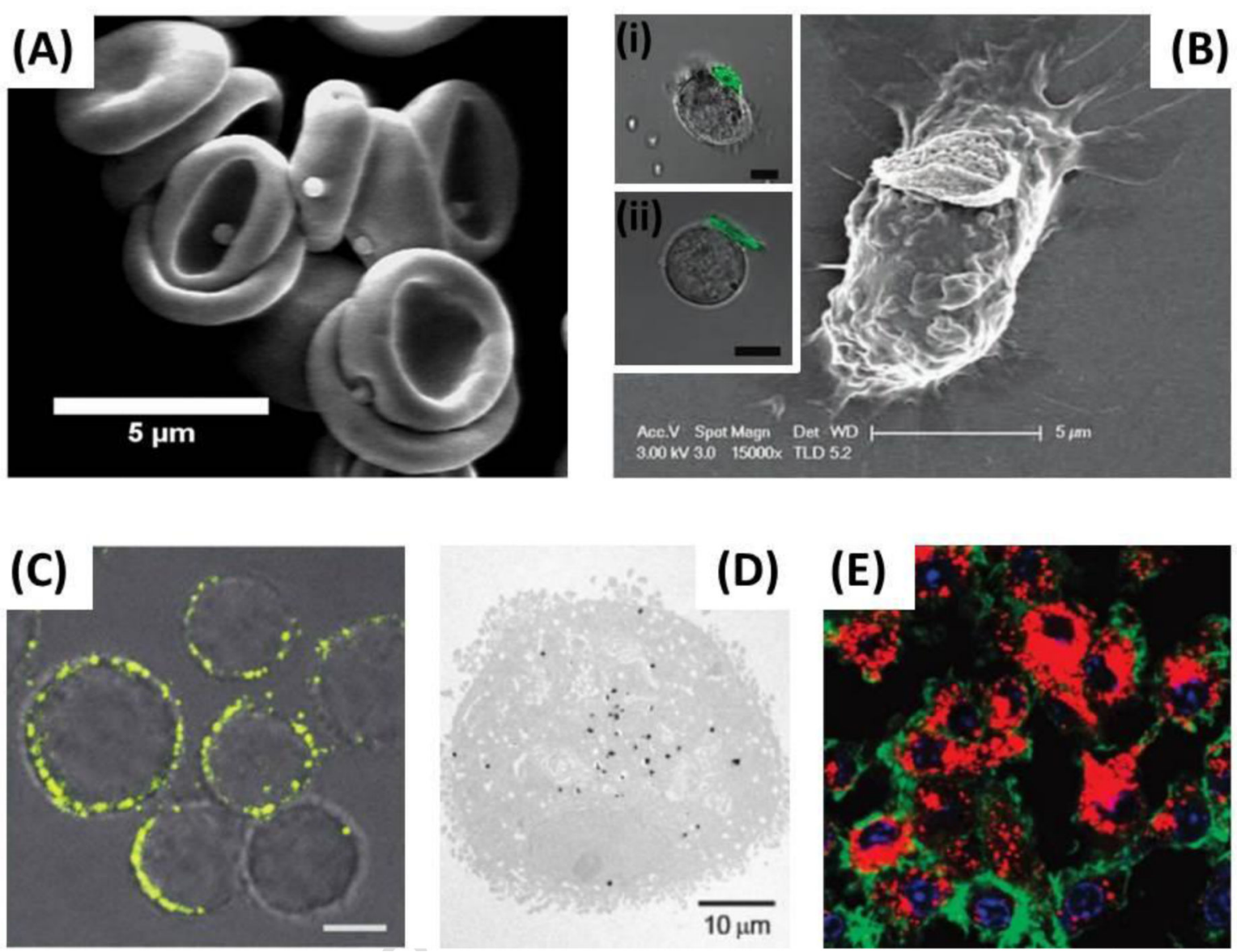

Figure 2.

Attachment of nanoparticles to circulatory cells. Various methods for incorporating nanoparticles either into or onto the surface of circulatory cells have been employed. (A) Passive adsorption: in this case, adsorption was mediated via hydrophobic, electrostatic, van der Waals and hydrogen bonding to reversibly attach polystyrene nanoparticles to the surface of red blood cells. Adapted with permission from [30]. Copyright (2013) American Chemical Society. (B) Receptor-ligand conjugation: in this case, hyaluronic acid (ligand) functionalized cellular backpacks were attached to the CD44 (receptor) rich surface of macrophages, T-cells (inset $\mathrm{i}$ ) and B-cells (inset ii). Inset scale bars $=10 \mu \mathrm{m}$ (B) Adapted with permission from [59]. Inset $2 \mathrm{~B}(\mathrm{i})$ and $2 \mathrm{~B}$ (ii) adapted with permission from [56]. Copyright (2008) American Chemical Society. (C) Covalent conjugation: in this case, the thiol rich T-cell surface was directly conjugated with maleimide functionalized liposomes. Scale bar $=2 \mu \mathrm{m}$. Adapted by permission from Macmillan Publishers Ltd: Nature Medicine [60], copyright (2010). (D and E) Internalization of nanoparticles by cells: in this case, gold nanoparticles (D) and catalase nanozymes (E) were incubated with, and internalized by, macrophages. (D) Adapted with permission from [61]. Copyright (2007) American Chemical Society. (E) Adapted with permission from [62]. Copyright (2007) American Chemical Society 

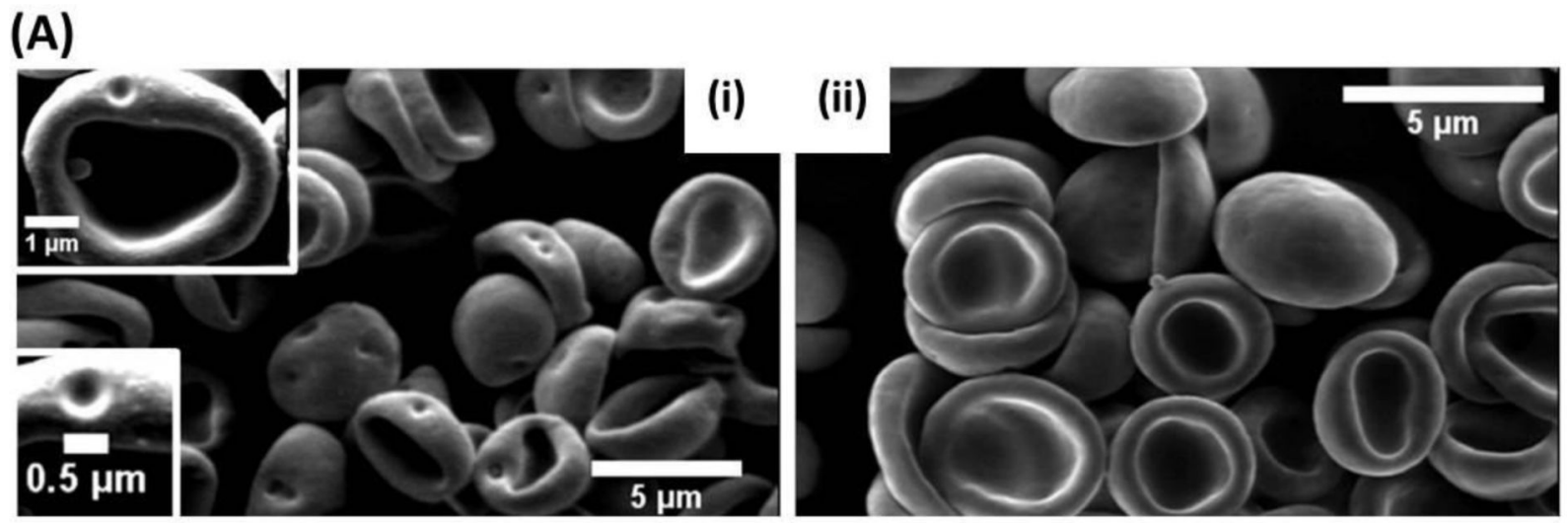

(B)
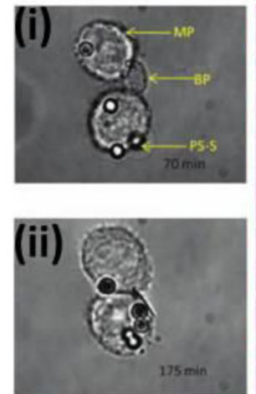

(D)

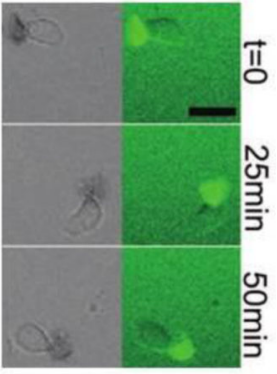

(C)

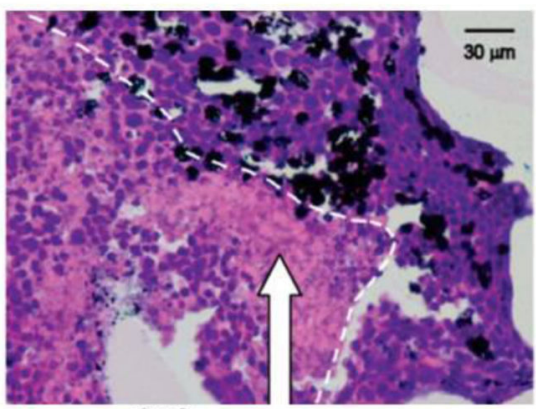

(E)

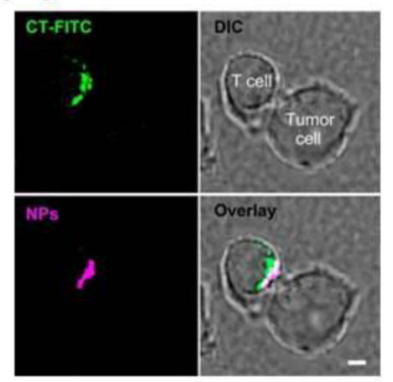

(F)

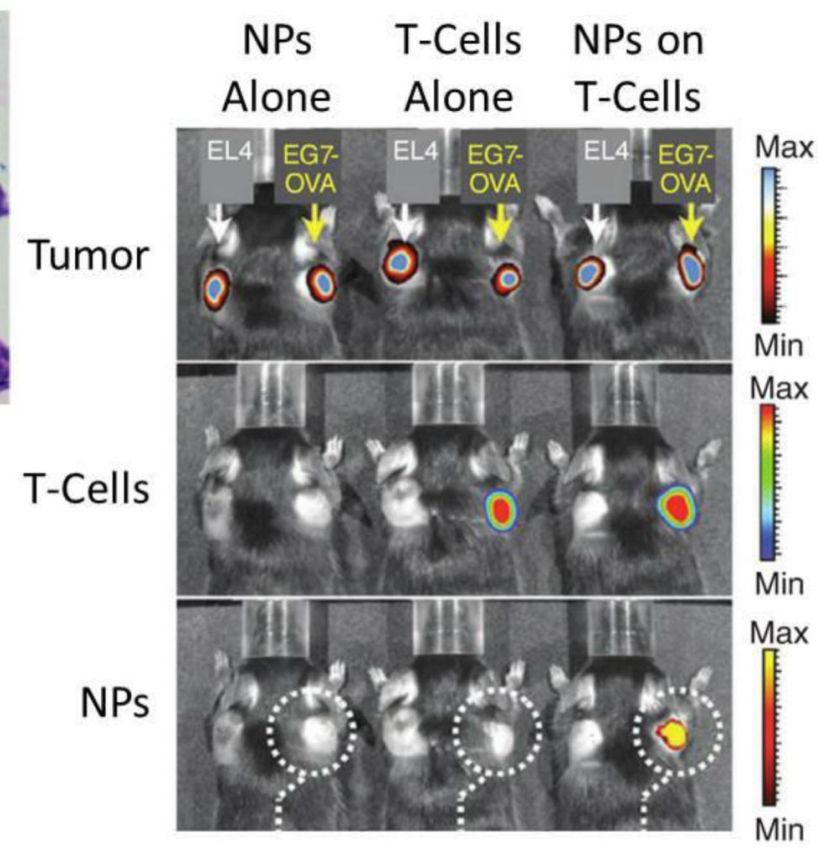

Figure 3.

Cells are not damaged and maintain their innate functions following nanoparticle hitchhiking. (A) $500 \mathrm{~nm}$ polystyrene nanoparticles leave an indent on red blood cells when red blood cell membrane is fixed prior to nanoparticle detachment (inset i). However, upon membrane fixation after nanoparticle detachment, no indent is seen (inset ii). This suggests that while nanoparticles are attached, the red blood cell membrane spreads to accommodate attachment but upon detachment, the red blood cell membrane reversibly returns to its normal structure. Adapted with permission from [30]. Copyright (2013) American Chemical Society. (B) Macrophages functionalized with cellular backpacks via the CD44 receptor are still able to phagocytose polystyrene beads (inset i). The cellular backpack was not internalized for the duration of the experiment (inset ii). (B) Adapted with permission from [59]. (C) Macrophages with gold nanoshells internalized (black) travel into tumor spheroids and accumulate around the hypoxic areas (pink stained cells). (C) Adapted with permission from [61]. Copyright (2007) American Chemical Society. (D) A cellular backpack laden T- 
cell migrates on ICAM-1 coated slides, mimicking the routine migration that T-cells undergo in vivo. Scale bar $=25 \mu \mathrm{m}$. Adapted with permission from [56]. Copyright (2008) American Chemical Society. (E) T-cells homogenously functionalized with liposomes interact with target cancer cells. Liposomes reorient at the point of contact and improve Tcell receptor activation during interaction with cancer cells. Scale bar $=2 \mu \mathrm{m}$. Reprinted from [65] with permission from Elsevier. (F) T-cells with affinity for OVA and functionalized with liposomes are able to home to EG7-OVA tumors exclusively. Adapted by permission from Macmillan Publishers Ltd: Nature Medicine [60], copyright (2010). 

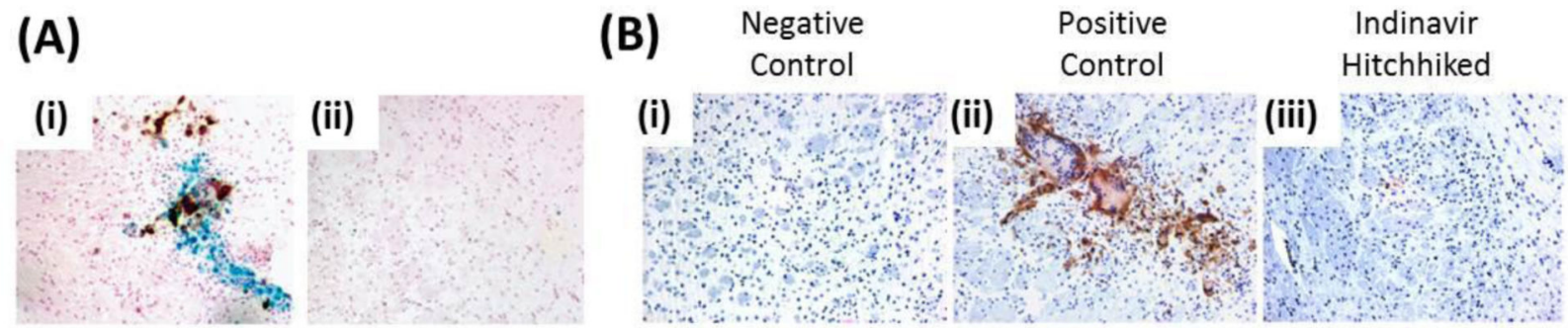

(C)

(i)

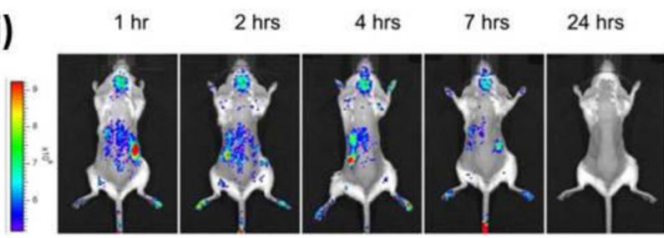

(ii)

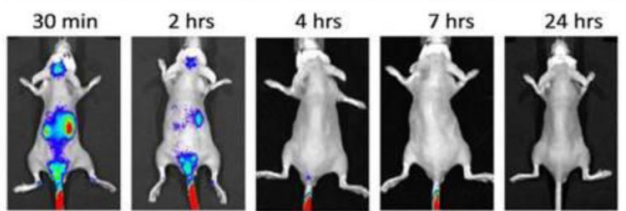

(D)

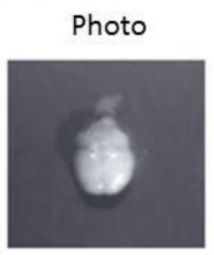

Metastases

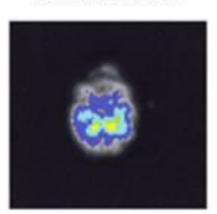

Nanoparticles

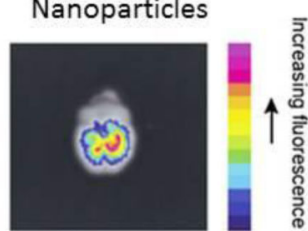

(E)

Tumor

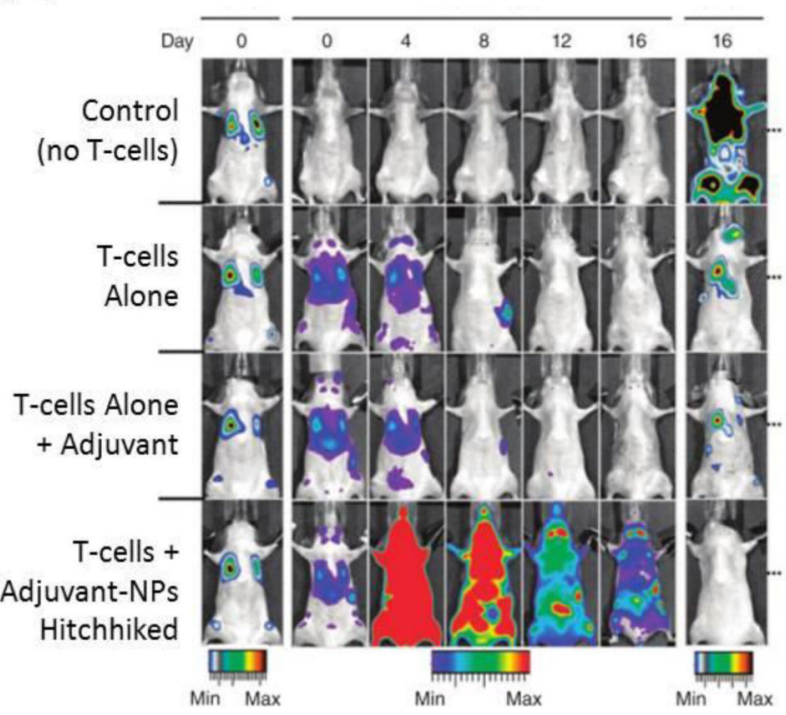

Figure 4.

Applications of Cellular Hitchhiking. (A) Histology images of brain tissues showing macrophages loaded with iron oxide nanoparticles (stained blue) are able to traverse the blood brain barrier and home to HIV infected brain tissue (stained brown) in HIV infected mice (inset i). No nanoparticles or HIV infection are detected in control mice (inset ii). Adapted with permission from [66]. Copyright 2009. The American Association of Immunologists, Inc. (B) Histology images of brain tissues showing: (inset i) negative control in normal mice, (inset ii) positive control of HIV infected cells (stained brown) in mouse brain and (inset iii) indinavir loaded macrophage treated mice showing reduced infection. Adapted with permission from [66]. Copyright 2009. The American Association of Immunologists, Inc. (C) Real time tracking of nanozymes in an MPTP induced Parkinson's Disease model shows increased delivery of nanozymes via macrophages (inset i), and likely catalase, and persistence in the brain compared to nanozymes alone (inset ii). Adapted from Nanomedicine [63] with permission of Future Medicine Ltd. (D) Human whole blood derived monocytes/macrophages target brain metastases. Adapted with permission from [67]. (E) Hitchhiked T-cells functionalized with adjuvant liposomes completely eradicate lung and bone metastases unlike T-cells alone, T-cells with non-hitchhiked adjuvants and control groups. Adapted by permission from Macmillan Publishers Ltd: Nature Medicine [60], copyright (2010). 


\section{Table 1}

Examples of cells used for in vivo applications.

\begin{tabular}{|c|c|c|}
\hline Cell Type & Therapeutic Class & In Vivo Application \\
\hline Red Blood Cells & Enzymes & $\begin{array}{l}\text { Tissue plasminogen activator attached to red blood cell surface used to dissolve clot } \\
\text { [69] } \\
\text { Alcohol oxidase loaded into red blood cells decreased methanol concentration in blood } \\
\text { compared to controls [70] }\end{array}$ \\
\hline Red Blood Cells & Drugs & $\begin{array}{l}\text { Azidothymidine loaded into red blood cells used to enhance anti-viral potency in HIV } \\
\text { mouse model [71] } \\
\text { Clodronate loaded into red blood cells used to deplete macrophage populations [72] } \\
\text { Dexamethasone } 21 \text {-phosphate loaded into red blood cells for extended release and blood } \\
\text { persistence of drug for up to } 7 \text { days [25] }\end{array}$ \\
\hline Red Blood Cells & Cytokines & Interleukin 2 coated on red blood cell surface reduced tumor size over $80 \%$ [73] \\
\hline Dendritic Cells & Immunotherapy & $\begin{array}{l}\text { Antigen pulsed dendritic cells induced antitumor cellular immune responses and tumor } \\
\text { regression [74] } \\
\text { Peptide pulsed dendritic cells showed some metastatic regression in Phase I trials [75] } \\
\text { Peptide pulsed dendritic cells provide protection against lethal tumor challenge [76] }\end{array}$ \\
\hline T-Cells & Viral Vectors & $\begin{array}{l}\text { Viral vectors were loaded onto the surface of T-cells for curing of established metastatic } \\
\text { disease [77] }\end{array}$ \\
\hline T-Cells & Adoptive Cell Therapy & T-cells are widely used for cancer immunotherapies $[41,78,79]$ \\
\hline Natural Killer Cells & Adoptive Cell Therapy & $\begin{array}{l}\text { Natural killer cells are s used for various immunotherapies with many showing } \\
\text { antitumor effects [80] }\end{array}$ \\
\hline Platelets & $\begin{array}{l}\text { Platelet Rich Plasma } \\
\text { (PRP) }\end{array}$ & $\begin{array}{l}\text { Collagen-hydrogel scaffold containing PRP used to improve biomechanical properties } \\
\text { at early time points in ACL repair [81] }\end{array}$ \\
\hline
\end{tabular}




\begin{tabular}{|c|c|c|c|c|c|c|c|c|c|}
\hline & 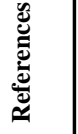 & $\begin{array}{l}\overline{\mathrm{d}} \\
\infty \\
\stackrel{d}{\mathrm{~d}}\end{array}$ & $\bar{\varnothing}$ & $\sqrt{6}$ & 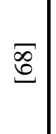 & $\underset{\mathscr{D}}{\sigma}$ & $\overline{\hat{\sigma}}$ & $\bar{B}$ & $\sqrt{\underline{6}}$ \\
\hline & 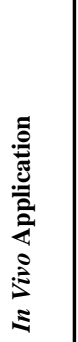 & 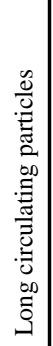 & 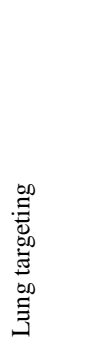 & 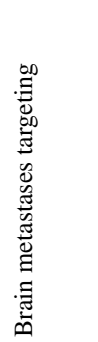 & 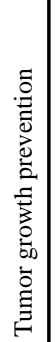 & 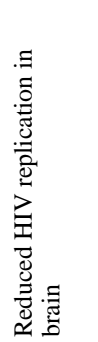 & 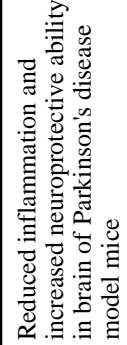 & 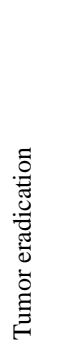 & 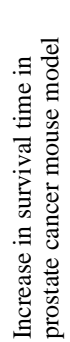 \\
\hline & 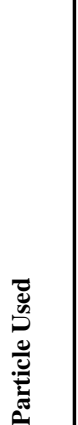 & 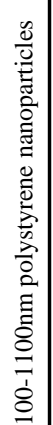 & 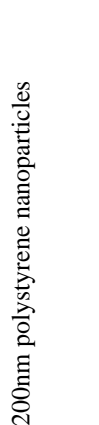 & 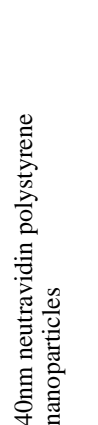 & 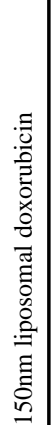 & 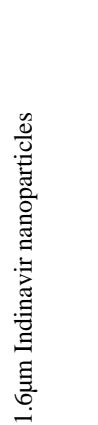 & 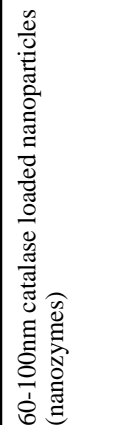 & 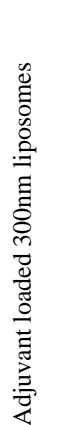 & 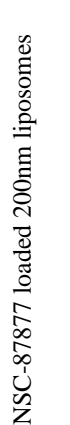 \\
\hline 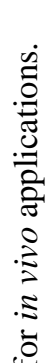 & 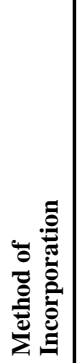 & 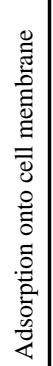 & 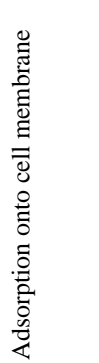 & 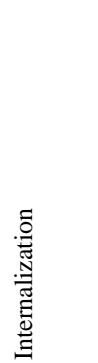 & 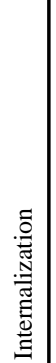 & 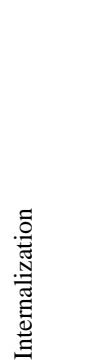 & 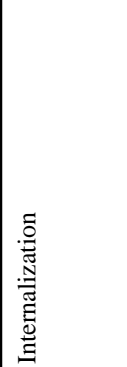 & 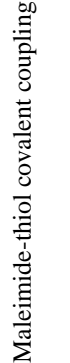 & 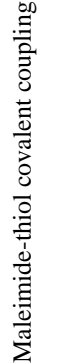 \\
\hline 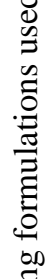 & 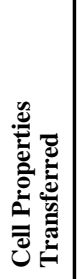 & 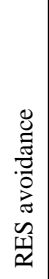 & 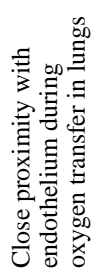 & 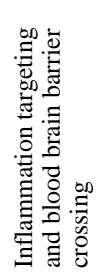 & 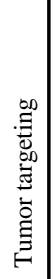 & 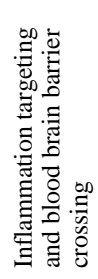 & 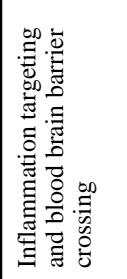 & 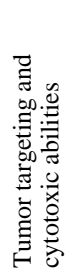 & 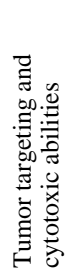 \\
\hline 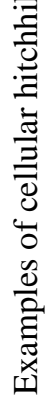 & 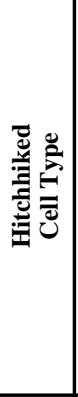 & 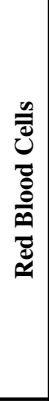 & 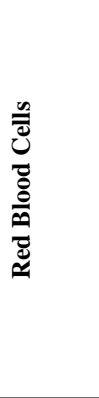 & 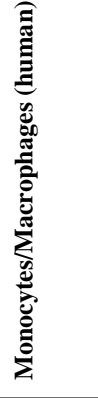 & 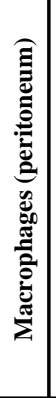 & 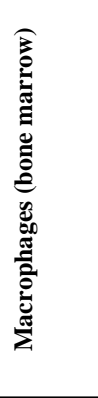 & 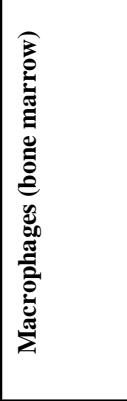 & بِ & 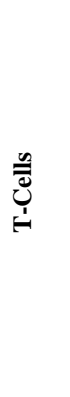 \\
\hline
\end{tabular}

J Control Release. Author manuscript; available in PMC 2015 September 28. 
Table 3

The abilities of the ideal drug delivery carrier, the ways that nanoparticles can potentially perform ideal carrier abilities and the issues nanoparticles face with achieving this and the solution cellular hitchhiking offers.

\begin{tabular}{|c|c|c|c|}
\hline Ideal Carrier Abilities & Nanoparticle Solution & $\begin{array}{l}\text { Issues with Nanoparticle } \\
\text { Solution }\end{array}$ & Cellular Hitchhiking Solution \\
\hline $\begin{array}{l}\text { Long Circulation: } \\
\text { Allows for multiple passes and } \\
\text { interactions with target site }\end{array}$ & $\begin{array}{l}\text { Stealth coatings: Hydrophilic } \\
\text { polymers (PEG) } \\
\text { Cell-derived stealth ligands } \\
\text { (CD47) }\end{array}$ & $\begin{array}{l}\text { PEG may cause immune } \\
\text { response } \\
\text { Cell-derived ligands may } \\
\text { bind to multiple receptors and } \\
\text { cause unwanted responses }\end{array}$ & $\begin{array}{l}\text { All cells have natural stealth properties } \\
\text { and can circulate for long periods of } \\
\text { time }\end{array}$ \\
\hline $\begin{array}{l}\text { Targeting to Diseased Tissue: } \\
\text { Facilitates drug delivery to target } \\
\text { site and avoids off-target side } \\
\text { effects }\end{array}$ & $\begin{array}{l}\text { Functionalization with tissue } \\
\text { specific peptides, proteins or } \\
\text { antibodies. }\end{array}$ & $\begin{array}{l}\text { Nanoparticle uptake in liver } \\
\text { and spleen is difficult to } \\
\text { mitigate which leads to off- } \\
\text { target side effects and } \\
\text { hepatotoxicity issues }\end{array}$ & $\begin{array}{l}\text { Cells naturally target diseased tissue } \\
\text { and negotiate near-impermeable } \\
\text { biological barriers }\end{array}$ \\
\hline $\begin{array}{l}\text { Controlled Drug Release: } \\
\text { Ensures sufficient delivery and } \\
\text { dosing to target cells }\end{array}$ & $\begin{array}{l}\text { Tuning particle composition } \\
\text { to control drug release rates }\end{array}$ & $\begin{array}{l}\text { None, as nanoparticles are } \\
\text { best suited for controlled } \\
\text { release of drugs }\end{array}$ & $\begin{array}{l}\text { Can utilize controlled release abilities } \\
\text { of nanoparticles }\end{array}$ \\
\hline $\begin{array}{l}\text { Biocompatible/Biodegradable: } \\
\text { Limits immune response and } \\
\text { facilitates degradation and } \\
\text { eventual removal from body }\end{array}$ & $\begin{array}{l}\text { Use of biodegradable } \\
\text { polymers (PLGA) }\end{array}$ & $\begin{array}{l}\text { Functionalization of } \\
\text { biodegradable nanoparticles } \\
\text { (PEG, antibodies) can still } \\
\text { cause immune response and } \\
\text { long-term effects are widely } \\
\text { unknown }\end{array}$ & $\begin{array}{l}\text { Cells are biocompatible and are } \\
\text { naturally degraded }\end{array}$ \\
\hline $\begin{array}{l}\text { Multifunctional: } \\
\text { Successful drug delivery requires } \\
\text { all previously listed abilities to be } \\
\text { performed simultaneously }\end{array}$ & $\begin{array}{l}\text { Multi-ligand decorated } \\
\text { nanoparticles and } \\
\text { combinations of the above }\end{array}$ & $\begin{array}{l}\text { Clinical success of single- } \\
\text { functional nanoparticles is } \\
\text { limited, much less } \\
\text { multifunctional }\end{array}$ & $\begin{array}{l}\text { Cells perform multiple functions, } \\
\text { including those listed under "Ideal } \\
\text { Carrier Abilities" }\end{array}$ \\
\hline
\end{tabular}


Table 4

Methods, advantages and disadvantages of nanoparticle attachment techniques to cells.

\begin{tabular}{|c|c|c|c|}
\hline Attachment Method & Advantages & Disadvantages & Ideal Cell Type \\
\hline $\begin{array}{c}\text { Adsorption } \\
\text { (Electrostatic and } \\
\text { Hydrophobic) }\end{array}$ & $\begin{array}{l}\text { No cell preparation } \\
\text { Minimal particle requirements: } \\
\text { (hydrophobic or positively charged) }\end{array}$ & $\begin{array}{l}\text { Attachment may not be strong: } \\
\text { Particles may detach } \\
\text { unpredictably in vivo } \\
\text { Positively charged particles } \\
\text { can damage cell membranes }\end{array}$ & $\begin{array}{l}\text { Cells that persist in circulation: Red } \\
\text { blood cells and platelets } \\
\text { Cells that traverse endothelium may } \\
\text { cause unwanted particle detachment } \\
\text { during migration }\end{array}$ \\
\hline Ligand-Receptor & $\begin{array}{l}\text { Can potentially be used to attach } \\
\text { particles to cells in vivo since } \\
\text { attachment is mediated by specific } \\
\text { cell receptors }\end{array}$ & $\begin{array}{l}\text { Ligand-receptor interaction } \\
\text { may signal specific cellular } \\
\text { functions }\end{array}$ & $\begin{array}{l}\text { Cells that express sufficient receptors } \\
\text { which allow for multivalent binding: } \\
\text { CD44-hyaluranon interaction allows for } \\
\text { stable multivalent bonding to multiple } \\
\text { cell types }\end{array}$ \\
\hline $\begin{array}{c}\text { Covalent Coupling } \\
\text { Maleimides or } \\
\text { Carboxylates or } \\
\text { Succinimidyl Esters } \\
+\end{array}$ & $\begin{array}{l}\text { Offers the strongest bond between } \\
\text { particle and cell } \\
\text { Conjugate directly to amine or thiol } \\
\text { groups present on all cells } \\
\text { (membrane proteins) }\end{array}$ & $\begin{array}{l}\text { Requires permanent } \\
\text { modification to cell surface }\end{array}$ & $\begin{array}{l}\text { Cells that migrate through endothelium: } \\
\text { Monocytes, macrophages and T-cells } \\
\text { since particle attachment must be strong }\end{array}$ \\
\hline 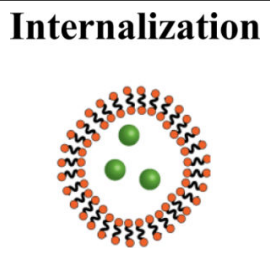 & $\begin{array}{l}\text { Leaves the cell membrane } \\
\text { unmodified } \\
\text { Can carry particles through } \\
\text { endothelium }\end{array}$ & $\begin{array}{l}\text { Can lead to degradation of } \\
\text { internalized biodegradable } \\
\text { particles }\end{array}$ & Cells capable of phagocytosis \\
\hline
\end{tabular}

